\title{
Scientific and methodological foundations of the influence of the social and psychological properties of the manager on managerial decisions
}

\author{
Azamat NAZAROV 1 \\ International Islamic Academy of Uzbekistan
}

\begin{tabular}{l} 
ARTICLE INFO \\
\hline Article history: \\
Received March 2021 \\
Received in revised form \\
20 March 2021 \\
Accepted 15 April 2021 \\
Available online \\
20 May 2021 \\
\\
\hline Keywords: \\
personality, \\
staff, \\
manager, \\
individual personality traits, \\
management, \\
making decisions, \\
conscious choice, \\
determinism, \\
indeterminism.
\end{tabular}

\section{ARTICLE INFO}

Article history:

Received March 2021

Received in revised form

Accepted 15 April 2021

Available online

20 May 2021

Keywords:

personality,

manager,

individual personality traits,

management

determinism

\section{ABSTRACT}

The article describes the psychological characteristics of the decision-making process in management activities and the results of experimental work in this area, gives psychological advice to improve the efficiency of the management decisionmaking process. In the process of developing management decisions, the basics of the importance of personal qualities and features of the manager's business behavior are described. It is proved that the organizational and socio-psychological aspects of management make it possible to organize the manager's knowledge of the personnel management mechanisms, the action of the means that influence the behavior of the individual, the regulation and organization of the labor activity of subordinates.

The development of effective solutions in the modern conditions of the economy of Uzbekistan is the basis for the competitiveness of products and the self-sufficiency of the organization in the market, the formation of rational organizational structures, the implementation of proper personnel policy and work, the regulation of social and political relations, and the creation of a positive image.

2181-1415/C 2021 in Science LLC.

This is an open access article under the Attribution 4.0 International (CC BY 4.0) license (https://creativecommons.org/licenses/by/4.0/deed.ru)

\footnotetext{
${ }^{1}$ Lecturer, International Islamic Academy of Uzbekistan Tashkent, Uzbekistan.

E-mail: a.nazarov.80@mail.ru.
} 


\section{Рахбарнинг ижтимоий-психологик хусусиятларини бошқарув қарорларига таъсирининг илмий-методологик асослари}

\author{
Калит сўзлар: \\ шахс, \\ персонал, \\ менеджер, \\ шахснинг идивидуал \\ хусусиятлари, \\ менежмент, \\ қарор қабул қилиш, \\ бошқарув қарорлари, \\ онгли танлов, \\ детерминизм, \\ индетерминизм.
}

\section{АННОТАЦИЯ}

Мазкур мақолада бошқарув фаолиятида қарор қабул қилиш жараёнининг психологик хусусиятлари ва бу борада олиб борилган тажриба-синов ишлари натижалари бошқарув қарорларини қабул қилиш жараёни самарадорлигини оширишга хизмат қилувчи психологик маслахатлар баён этилади. Бошқарув қарорларини ишлаб чиқиш жараёнида менежернинг шахсий фазилатлари ва ишбилармонлик хатти-харакатлари хусусиятларининг ахамияти асослари берилган. Менежментнинг ташкилий ва ижтимоий-психологик жихатлари менежернинг кадрларни бошқариш механизмлари, шахснинг хулқ-атворига таъсир этувчи воситаларнинг ишлаши, бўйсунувчиларнинг мехнат фаолиятини тартибга солиш ва ташкил этиш тўғрисидаги билимларини ташкил этиши исботланган.

Ўзбекистон иқтисодиётининг замонавий шароитида самарали ечимларни ишлаб чиқиш махсулотларнинг рақобатбардошлигини ва бозорда ташкилотнинг ўзини таъминлашнинг асоси рационал ташкилий тузилмаларни шакллантириш, тўғри кадрлар сиёсати ва ишларини амалга ошириш, корхонада ижтимоий-сиёсий муносабатларни тартибга солиш, ижобий имидж яратиш хисобланади.

\section{Научно-методические основы влияния социально- психологических свойств руководителя на управленческие решения}

\author{
Ключевые слова: \\ личность, \\ персонал, \\ менеджер, \\ индивидуальные \\ особенности личности, \\ менеджмент, \\ принятие решений, \\ управленческие решения, \\ осознанный выбор, \\ детерминизм, \\ индетерминизм.
}

\begin{abstract}
АННОТАЦИЯ
В статье изложены психологические особенности процесса принятия решений в управленческой деятельности и результаты экспериментальной работы в этой области, даны психологические советы по повышению эффективности процесса принятия управленческих решений. В процессе выработки управленческих решений описываются основы важности личных качеств и особенности делового поведения менеджера. Доказано, что организационные и социально-психологические аспекты менеджмента позволяют организовать знание менеджером механизмов управления персоналом, действие средств, влияющих на поведение личности, регулирование и организацию трудовой деятельности подчиненных.

Разработка эффективных решений в современных условиях экономики Узбекистана является основой конкурентоспособности продукции и самодостаточности организации на рынке, формированием рациональных организационных структур, реализацией надлежащей кадровой политики и работы, регулированием общественно-политических отношений, созданием положительного имиджа.
\end{abstract}




\section{INTRODUCTION}

Today's social events are reflected in the human mind. Science, as a form of social consciousness, reflects the characteristics of its time. In this sense, there is a turning point in the development of modern psychology. Until recently psychology, with its emphasis on theoretical issues, has now taken a number of practical steps. Such tasks are, in the end, connected with the creation of new comfortabilities for the benefit of the people. The modern history of the Republic of Uzbekistan is based on the formation of a democratic state. Active participation of the people in this important process has crucial influence in the process of democratic reforms in all spheres of social life of the country. Uzbekistan as an independent state is transforming its management system in line with its national development in the process of transition to a market economy, with the emergence of a new form of ownership, economic relations and ownership. The main direction of the reform of the management system was "Raising the effectiveness of the management system to a new level, significantly improving the quality of decision-making and forming, moreover introducing an effective mechanism for controlling their implementation".

Proper preparation and decision making in modern management creates opportunities for achieving managerial effectiveness in all areas of socio-political, sociopsychological and economic life.

Decision-making process is a specific type of labor activity that requires a high level of professionalism and experience. Generally, management decisions are directed towards a particular purpose, and a certain rule is implemented within specific actions.

The relevance of exploring the democratic basis of decision making in public administration is related to a number of objective reasons:

First of all, consistent study of the decisions taken in the field of public administration, taking into account the main reforming role of the state in the ongoing reforms in the country, is a requirement of the time.

Secondly, the adoption of managerial decisions aimed at improving the efficiency of public administration is becoming a necessity today.

Third, the analysis of the essence of managerial decisions made in our country over the independence period allows us to understand the essence of the socio-political and socio-psychological processes in Uzbekistan and identify promising areas.

Fourth, public awareness and control over the decision-making process and their participation in governance will contribute to further community accountability.

It is desirable to use the achievements of world science and the experience of developed countries, as well as national traditions of national governance in the effective implementation of reforms. Whether it is strategic reform or decisions made in day-to-day activities, it is important to take them into account when making those decisions, as well as ensuring that the expected, or more precise, results are achieved. A well-thought-out situation can be said to be half the way to achieve the outcome of decisions that have been made without thorough analysis. That is, making the right decision increases the chances of achieving the goal.

Indeed, it is worth recalling the words of Amir Temur: "I did all my tasks with counsel and accomplished them with the right method. Before I started something, I worked out ways of dispensation. I would end it with the right action, determination, patience, perseverance and cautious far-sightedness". 
It is well known that one of the key aspects of managing an organization is making managerial decisions and enforcing them. Management decisions are expressed in terms of bringing an object in the organization from one state to another for the intended purpose. Therefore, management decisions are one of the key socio-psychological and economic factors that determine the future of the organization. In this regard, efforts are being made on socio-economic science to make decisions in management and the sociopsychological characteristics of the made decisions.

Knowledge of the psychological aspect of the decision-making process allows us to make existing steps more effective. The point is that in order to make the right decision and implement it effectively, the leader must follow certain psychologically relevant actions. The main point of this event is that as the leader collects information about the problem, he begins to create an initial picture of the problem - an information model. The relevance of this model to reality and the current situation depends on the completeness and variety of the information received.

Thus, the foregoing considerations are first and foremost a human factor in decisionmaking, and secondly, to determine each individual's inner capacity, ability to think through and make critical decisions and the ability to perform in the face of difficult situations that arise in his or her work. It is worth noting that our research work on this topic is relevant.

\section{LITERATURE REVIEW}

Models, technologies, socio-political and socio-psychological characteristics of decision-making in management, and the term "decision-making" was first used by American scholars in the 1930s, by C. Bernard, E. Stein and etc. They used the term to describe decentralization of social and organizational processes. In the 1960s, this theory was developed by G. Simon and D. Marks. Various aspects of this theory are currently being developed within the theory of social processes modeling in economics, sociology, political science, and social psychology.

The decision-making process, the adoption of rational and effective legislation, and the preparation of other documents have long attracted the attention of scientists. Ancient philosophers such as Plato, Kautilya and Shan Yan contributed greatly to the theory of public administration. However, it is Aristotle who, in fact, developed the first theory of decision-making. Aristotle described a set of categories that characterize the decisionmaking process and developed a theoretical framework for the process. In his analysis, he derived from the notions of "reasoning" (phronesis) and "conscious choice". According to Aristotle, man's ability to think is manifested in two forms: theoretical wisdom and practical reasoning. Consequently, when the basis of fundamental science is theoretical, the practical knowledge is based on practical reasoning.

The second basic concept is that the "conscious choice" refers to the voluntary nature and ambiguity of human activities in pursuit of a particular goal. Aristotle noted that decisions do not only cover the ultimate goal, but also give greater attention to the means by which they are implemented. Thus, according to Aristotle, managerial decisionmaking is an analytical and practical activity and is a discipline primarily focused on the rational and conscious choice of appropriate means; and second, to find the most effective ways to achieve the goal in the context of uncertainty, voluntariness and free choice.

Its known from the sources, that the issue of rational and expedient decision-making by government decisions has been consistently studied by Renaissance thinkers 
(N. Maciavelli, J. Boden and others) and educators (T. Gobbs, B. Spinoza, J.J. Russo, etc.). Specifically, sorting out state decisions, N. Makiavelli and T. Gobbs discuss the rulers' advisers and their advice. B. Spinoza and J.J. Rousseau analyze the specifics of voting in representative bodies and public assemblies, and J. Boden emphasizes the need to consider social conditions in decision-making. The opinions of these authors are still relevant today.

The psychological analysis of the decision-making process, above all, aims at improving the performance of the manager or executor. In this regard, there is a need to examine the socio-psychological and personal characteristics that impede the management and staff, the tendency to fulfill them, and the choice of optimal path in decision-making activities.

World science has a prestigious scientific potential associated with management decision-making. In particular, V.N. Spitsnadel's Theory and Practice of Effective DecisionMaking, Theory and Methods of Decision-making by O.I. Larichev, and E.A.Smirnov's Theory of Decision-Making have included a great deal of theoretical insight and practical guidance on decision-making.

A.I. Solovyov "Political Science, Political Theory, Political Technology", V.I. Korring "Theory, Practice and Art of Management", D.P. Zerkin and G.G. Ignatov "Fundamentals of Public Administration Theory", The essence and features of managerial decision-making in the works of G.V. Pushkareva "Political Management", by local scientists E.G. Goziev "Management psychology", I. Makhmudov "Management psychology" and N. Boymuradov "Leader psychology" revealed.

However, it is evident that the socio-psychological aspects of decision-making in management are insufficiently studied today in the world psychology.

1. Before delving into the theory of decision-making, it is advisable to comment on the concept of "decision", in particular, the concept of "management decision". Generally, decision-making refers to a particular type of human activity that seeks to choose the best of alternatives. There are different definitions of the word "decision". In other words, the solution is to choose a specific way of doing things. In other words, the solution is to come to a stop or think in choosing a particular path.

"The decision", writes E. Smirnov, "is the product of the mental activity of the person, the conclusion that leads to a particular action. The decision is for a specific purpose and may be aimed at achieving a short- or long-term task, continuing or stopping the process". Therefore, the decision is the product of mental activity, planning and regulating its activities.

Decision-making is a complex process of thinking, understanding the problem, setting an adequate goal, and choosing the means to achieve it.

Decision-making refers to a particular type of human activity that seeks to choose one of the alternatives - especially, the best one. This approach assumes that there are three elements to the selection process:

- The problem which must be solved;

- the person or team that makes the decision;

- More options for choosing.

Without any of these elements, the process of choice will not occur. This does not mean, however, that decisions are not made, but that decisions are made differently than those that are conscious. Depending on how management decisions are perceived as 
different (individual or organizational) process, four models of decision making can be distinguished [Table 1].

Table 1

\section{Management decision-making levels}

\begin{tabular}{|c|c|}
\hline $\begin{array}{c}\text { "PERSONAL LIMITED RATIONALIZATION" } \\
\text { MODEL } \\
\text { (personal satisfaction) }\end{array}$ & $\begin{array}{c}\text { RATIONAL MODEL } \\
\text { (organizational activation) }\end{array}$ \\
\hline $\begin{array}{c}\text { POLITICAL MODEL } \\
\text { (individual activity) }\end{array}$ & "ORGANIZED LIMITED RATIONAL" \\
MODEL \\
(organization's satisfaction)
\end{tabular}

The way the leader makes decisions. Lacking the ability to positively solve problems, a leader can control the development of the organization he or she leads, but can not bring it to the highest level. A creative thinker can handle the situation. The leader's exploration of team's feedback and decision-making approach for solving problems is as follows:

1. Scientific validity of the decision. Decisions should be made based on the analysis of specific production conditions, based on the economic, social and other modern scientific achievements.

2. Unity of decisions. Usually, you have to deal with minor issues as well as major issues.

3. Fairness, validity of decisions. Decisions can only be made with the authority given to managers.

4. Proper decision-making. Every decision should be clear to the executors and also to whom it is intended.

5. Complexity of decisions. Compact, precise decisions are taken to save time.

6. Timeliness of decisions. Supervisors should clearly state to their subordinates the timing of their tasks.

Speed of decisions. Such decisions can be made in a matter of minutes, when production conditions require it.

Management decisions are the final conclusions that have different meanings on various issues in governance. That is, the management decisions are a legal document adopted by the head, aimed at implementing certain measures to achieve certain results. Management decisions can be revealed in the forms of decisions, decrees, orders and other documents.

\section{RESEARCH METHODOLOGY}

As it is known, the effectiveness of decision-making in problematic situations largely depends on the individual and psychological characteristics of the decision-maker. Based on this, we sought to examine the personality and individual-psychological characteristics (temperament, character, relationships) of higher education management personnel. To do this, we used A. Kettel's 16 Factor Personality Survey. The questionnaire consists of 16 factors. In particular: Imaginative versus practical, Worried versus confident, Forceful versus submissive, Calm versus high-strung, Spontaneous versus restrained, Flexible versus attached to the familiar, Controlled versus undisciplined, Discreet versus open, 
Abstract versus concrete, Conforming versus non-conforming, Self-sufficient versus dependent, Tender-hearted versus tough-minded, Uninhibited versus shy, Impatient versus relaxed, Suspicious versus trusting, Outgoing versus reserved.

\section{ANALYSIS AND RESULTS}

Based on the results of R. Kettel's method of identifying managerial decisionmakers' characteristics, a number of aspects of personality traits which may improve decision-making process in higher education have been shown:

Factor 1. A. The leader's "Outgoing versus reserved" is one of the key factors in his / her preparation for the activity. This feature of respondents created a positive correlation with "boldness" (4.92). It is observed that the growth in communication and leadership in decision-making (6.47) can lead to increased courage and courage in working directly with subordinates and business contacts.

2. B - factor. The low Intelligence indicator in higher education management staff (3.46) contributes to "increased emotional instability (5.21), while" intellect increases the dominance of relationships. The rise of "Intellect" index, in turn, can be seen in the formation of a trustworthy internal connection in the manager. Decrease in intelligence can lead to lower efficiency in decision-making in troubled situations. [Table 2].

Table 2

Characteristics of personality in respondents by R. Kettel's test occurrence (in percent)

\begin{tabular}{|c|c|c|c|}
\hline \multirow{2}{*}{ FACTORS } & \multirow{2}{*}{ PERSONAL AND SOCIAL BASED FEATURES } & \multicolumn{2}{|c|}{ INDICATORS } \\
\hline & & Low & High \\
\hline The accuracy of the test & True or false & 46,7 & 53,3 \\
\hline A & Outgoing versus reserved & 4,92 & 6,47 \\
\hline B & Intellectual ability & 3,46 & 5,21 \\
\hline $\mathbf{C}$ & Emotional instability versus emotional stability & 6,92 & 6,96 \\
\hline $\mathbf{E}$ & Forceful versus submissive & 6,89 & 7,22 \\
\hline $\mathbf{F}$ & Calm versus high-strung & 6,68 & 7,10 \\
\hline G & Spontaneous versus restrained & 8,46 & 6,61 \\
\hline $\mathrm{H}$ & Uninhibited versus shy & 5,98 & 7,19 \\
\hline I & Tender-hearted versus tough-minded & 6,84 & 6,49 \\
\hline $\mathrm{L}$ & Suspicious versus trusting & 8,50 & 5,08 \\
\hline $\bar{M}$ & Imaginative versus practical & 4,76 & 4,26 \\
\hline $\mathbf{N}$ & impudence versus diplomacy & 4,88 & 5,14 \\
\hline 0 & Worried versus confident & 6,56 & 7,74 \\
\hline $\mathbf{Q}_{1}$ & Conservatism-radicalism & 5,86 & 6,30 \\
\hline $\mathbf{Q}_{2}$ & Flexible versus attached to the familiar & 3,86 & 4,18 \\
\hline$Q_{3}$ & Self-control low or high & 5,63 & 6,52 \\
\hline $\mathbf{Q}_{4}$ & Stress disposition high and low & 9,80 & 7,53 \\
\hline & TOTAL: & $100 \%$ & $100 \%$ \\
\hline
\end{tabular}

3. C - factor. Emotional instability increases the susceptibility of managers to emotional activity (6.92), and that certain managerial activities increase the dependence on performance and decision-making, and reduce self-control. Emotional stability reflects the probability of developing a strong control over their behavior $(6,96)$. 
4. E - Factor. Submissive versus forceful $(6,89-7,22)$ is reflected in the increase of "diplomacy" in relations.

5. Factor F. The Calm versus high-strung feature $F(6,68-7,10 \%)$ reported that respondents had anxiety and rigidity, characterized by their enthusiasm and general behavior.

6. E-Factor indicates that a person has these qualities, while demanding for their own behavior $(6,56-7,22)$, independence and leadership, and also indicates that they have low self-esteem and tend to subordinate to the circumstances and situation.

7. $\mathrm{N}$ - factor. impudence versus diplomacy points to the strong development of some of the managerial activities $(5.14-4.88 \%)$, the manifestation of emotion, the difficulty in communicating, the inability to understand the inner world of people, rudeness.

8. Q4 - Factor of Stress inclination and Stress resistance - Q4 $(9,80-7,53)$ indicates that respondents have symptoms of tension.

9. $\mathrm{M}$ - factor. Practicality in the process of action. The results of factor $\mathrm{M}(4,26-4,76)$, which contribute to the analysis of $\mathrm{M}$ characteristics, indicate that respondents have symptoms of abstraction, avoidance of specific situations and reality, and excitement.

10. Q1 - factor. Conservatism-radicalism $(5,86-6,30)$ points to the fact that the manager has low elasticity, the power to give in to a situation or circumstances.

11. Q2 - factor. Respondents' level of independence (4.18-34.83\%) showed a high degree of community dependence.

12. Q3 - factor. Self-monitoring of behavior (6.52-54.53\%) indicates low respondents' internal conformation, irresponsibility in the implementation of established social and legal requirements.

In the analysis of personality traits, we found that performance indicators $(A, B, C$, L, M, N, O, Q1, Q4) were significantly lower than those of management personnel. Such a development of personality traits can lead to the conclusion that management can not only influence the formation of key performance characteristics, but also impede future achievement in this area. In addition, managerial activities showed a lack of certainty in certain activities, lack of consensus, and clear direction.

It was also observed that some of those involved in management activities had low tolerance to emotional factors, lack of self-confidence, rapid excitement, and nervous system weakness. When analyzing such activities, we see a great deal of disagreement and controversy in their interpersonal relationships. Of course, they are more likely to be isolated from their teammates, colleagues and other people than to have family or friends.

From the foregoing, it can be noted that the individual-psychological traits that are inherent in the personality of managers involved in their management influence their system of interpersonal relationships and the effectiveness of managerial activities.

\section{CONCLUSIONS AND SUGGESTIONS}

Prospects for improving the management decision-making process are becoming a topical issue today. As country and public governance is built on democratic principles and the modern market economy, it is imperative that management decisions be drafted in accordance with these laws, and in turn, achieve better governance. It is also important to identify the specifics of management decisions, to improve them, and to train modern management personnel in the field, to develop skills and competencies in making wise management decisions. 
Based on the above, we consider it is advisable to take into account the following socio-psychological aspects of management decisions:

1. Knowledge of the psychological aspect of the decision-making process allows more efficient implementation of existing steps. In order to make the right decision and implement it effectively, the leader must adhere to certain criteria even psychologically.

2. It is necessary to carry out research (both psychological and pedagogical) in the process of making managerial decisions that can serve as a basis for accelerating reforms in the modernization of the country.

3. Ensure that the decision-making process combines theoretical knowledge with the creative imagination and foresight, and that the applied technologies are balanced with practical skills and qualifications.

4. Experience and observations show that some of the person in managerial activities have low tolerance to emotional factors, lack of self-confidence, excitement, and nervous system weakness. Ergo these persons are required to increase their selfconfidence, social and psychological activity.

5. The decision-makers' creative skills in relation to the objects studied in the decision-making process, such as the direct acquisition of knowledge, the choice of behavioral and heuristic methods of problem solving in non-standard situations, contribute to the success of the decision.

6. Taking into account a number of socio-psychological characteristics of managerial decisions: the psychology of demographic, ethno-psychological characteristics of national composition, accounting for specific socio-psychological consciousness of persons with certain values, managerial decision-making skills, level of socialization, mentality and focusing on human factor should be formed and taken into account.

7. At any level, a leader must imagine their rights and responsibilities. The leader must also have managerial skills and skills that are specific to the democratic and national ethno-psychological values of decision-making and implementation.

8. While the human factor is valued high in decision-making, it is advisable to encourage, create proper conditions and increase the level of professionalism of the key participants, decision makers and experts (staff, experts).

9. Emphasis on the positive impact of the team's psychological environment on the work, and the involvement of specialist psychologists. In other words, to study the sociopsychological aspects of management decisions by comparing Uzbekistan and the world, and expanding the scope of research in this area.

10. The role and influence of the character and temperament of the individual in decision-making are obvious.

\section{REFERENCES:}

1. Абдурахмонов У.F. ва бошкалар. Персонални бошқариш. - Т.: Шарқ, 1998.

2. Ларичев О.И. Теория и методы принятия решений. Учебник. - М.: Логос, 2000.

3. Ломакин А.Л. Управленческие решения. - М.: Форум- Инфра, 2005.

4. Махмудов И. Бошқарув психологияси. - Т.: УUNAKS-PRINT, 2006.

5. Назаров А. Психологические особенности руководителей, влияющие на принятие управленческих решений // Молодой ученый. - 2019. - №. 44. - С. 298-300.

6. Nazarov A.S. Psychological analysis of levels of administration of management decisions // Вопросы экономики и управления. - 2020. - №. 3. - С. 1-5. 
7. Умаров Б.М., Назаров А.С. Низоли вазиятларда бошқарув қарорларини қабул қилишнинг ташкилий ва ижтимоий-психологик механизмлари // Молодой ученый. - 2020. - №. 7. - С. 352-353.

8. Nazarov A.S. (2020). Қарор қабул қилиш бошқарув фаолиятининг психологик мезони сифатида. Молодой ученый, (11). - Б. 280-282.

9. Назаров А.С. (2020). Adoption of management decisions as the main function of the modern manager. In Проблемы современной экономики (PP. 7-12).

10. Назаров А.С., Худайбергенова 3. Socio-psychological features of management decision-making // Молодой ученый. - 2020. - №. 50. - С. 430-432.

11. Назаров А. C. Psychological aspects of managerial decision making // Молодой ученый. - 2020. - №. 44. - С. 45-48.

12. Назаров А.С. Принятие управленческих решений как основная функция современного менеджера // Вопросы экономики и управления. - 2020. - №. 2. - С. 1-5.

13. Nazarov A.S. Psychological foundations of managerial decision-making // Молодой ученый. - 2021. - №. 3. - С. 46-48.

14. Назаров A.C. The psychology of decision-making strategies // Актуальные научные исследования в современном мире. - 2021. - №. 1-7. - С. 79-82.

15. Назаров А.С. и др. Психологические особенности разработки и реализации управленческих решений // Актуальные научные исследования в современном мире. - 2021. - №. 2-9. - С. 31-35. 